\title{
SWEAT ANALYSIS IN FIBROCYSTIC DISEASE, CHRONIC PULMONARY DISEASE AND CONTROLS
}

BY

\author{
MARY M. WEEKS and G. A. BROWN \\ From the Department of Paediatrics and Child Health, the University of Birmingham, and \\ Birmingham Children's Hospital
}

(RECEIVED FOR PUBLICATION AUGUST 1, 1957)

Recent findings of abnormalities of sweat composition in patients with fibrocystic disease of the pancreas have stimulated broader interest in this disease and provided a new laboratory diagnostic procedure. A simplified method for collecting samples of sweat is presented, together with analytical results for sodium, chloride and urea concentrations in patients with fibrocystic disease and in patients with chronic pulmonary disease.

Previously described methods of sweat collection have required either special heating apparatus or controlled environmental humidity. Webb, Flute and Smith (1957) describe a method using enveloping polythene bags to encourage sweating and filter paper instead of pads of gauze to absorb the sweat.

The present method allows children to carry on with their normal activities during the collection. The small amounts of sweat obtained are adequate for analysis as the methods are the same as those used by Webb et al. with corresponding results. Gauze was found to be an advantage as the absorbed sweat and water did not require filtering before analysis.

The method described here, together with the analytical procedures, require no apparatus other than that available in any biochemical laboratory. In many centres the chloride content only of sweat is being estimated as this is considered diagnostic.

\section{Patients Studied}

Twenty children with proven fibrocystic disease of the pancreas, six children with chronic pulmonary disease unassociated with fibrocystic disease and six apparently healthy siblings of five of the fibrocystic patients were studied. Forty in-patients in whom there was no reason to suspect a sweat abnormality were selected as controls.

\section{Method}

The materials used were washed cotton gauze, transparent plastic sheeting and 1-in. wide waterproof adhesive strapping.

Ordinarily gauze contains small amounts of sodium chloride. All the 3-in. gauze squares used in the investigation were, therefore, prepared by first leaving them to soak in distilled water for two hours, and then completing the extraction of salt by passing approximately two gallons of distilled water through each 100 squares. They were dried at $70^{\circ} \mathrm{C}$.

A dry 50-ml.-flask containing a gauze square and closed by a ground-glass stopper was weighed. This piece of gauze was placed over the lumbar region of the patient, the site having been washed with distilled water and dried. It was covered with a larger square of plastic sheeting the edges of which were fixed to the skin with adhesive strapping to make an airtight seal.

The gauze was left in position for two to six hours, depending on the temperature of the external environment. It was then returned to the flask and reweighed, the weight of sweat thus being determined. At least $0 \cdot 1 \mathrm{~g}$. of normal sweat is required for accurate analysis, although 0.06 g. is sufficient in cases of fibrocystic disease of the pancreas.

Five millilitres distilled water were added to the flask which was restoppered and left for 12 hours.

The solution obtained by compressing the soaked gauze with a glass rod and decanting was used for estimating the chloride by mercurimetric titration, the sodium by flame photometry and the urea by urease and nesslerization. With very small amounts of sweat, extraction was performed by centrifuging the gauze in a tube containing a $1 \mathrm{~cm}$. length of narrow bore polythene

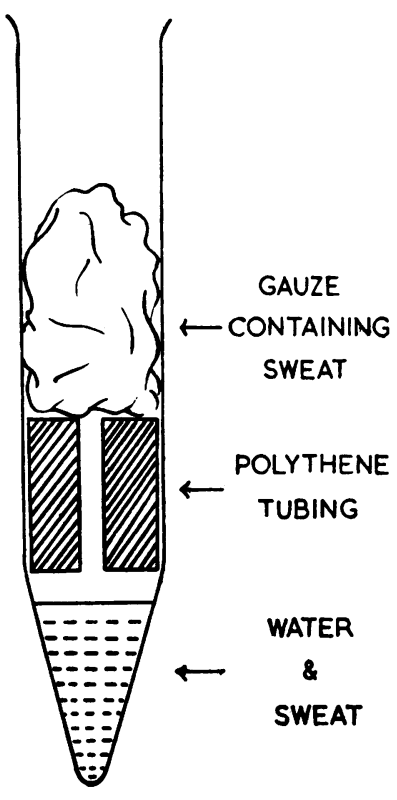

Fig. 1. 
TABLE 1

MEAN VALUES AND RANGES OF SODIUM AND CHLORIDES

\begin{tabular}{|c|c|c|c|c|c|}
\hline \multirow{2}{*}{ Group } & \multirow[b]{2}{*}{$\begin{array}{l}\text { Number } \\
\text { of Cases }\end{array}$} & \multicolumn{2}{|c|}{ Range } & \multicolumn{2}{|c|}{ Mean Values } \\
\hline & & $\begin{array}{l}\text { Sodium } \\
(\mathrm{mEq} / 1 .)\end{array}$ & $\begin{array}{l}\text { Chloride } \\
\text { (mEq/1.) }\end{array}$ & $\begin{array}{l}\text { Sodium } \\
(\mathrm{mEq} / 1 .)\end{array}$ & $\begin{array}{l}\text { Chloride } \\
(\mathrm{mEq} / 1 .)\end{array}$ \\
\hline 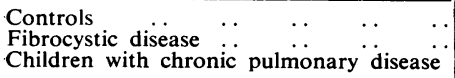 & $\begin{array}{r}40 \\
20 \\
6\end{array}$ & $\begin{array}{r}6 \cdot 6-37 \cdot 6 \\
36 \cdot 4-189 \cdot 4 \\
48 \cdot 1-69 \cdot 4\end{array}$ & $\begin{array}{r}6 \cdot 0-38 \cdot 4 \\
49 \cdot 6-196 \cdot 1 \\
20 \cdot 6-40 \cdot 5\end{array}$ & $\begin{array}{r}21 \cdot 2 \\
104 \cdot 0 \\
58 \cdot 2\end{array}$ & $\begin{array}{r}21 \cdot 8 \\
111 \cdot 5 \\
31 \cdot 5\end{array}$ \\
\hline
\end{tabular}

tubing fixed in a conical centrifuge tube (Fig. 1). On centrifuging, the sweat and water passed through the polythene tubing into the small chamber below, from which it was removed with the aid of a Pasteur pipette.

\section{Results}

Sodium and Chloride Concentrations. Mean values and ranges are summarized in Table 1, and the correspondence between sodium and chloride concentrations in individual specimens is shown in Fig. 2. It is evident from the graph that the concentrations of sodium and chloride are much greater in the children with fibrocystic disease than in the controls.

Sweat from six children with chronic pulmonary disease showed high sodium but normal chloride levels. This may be an important finding but its significance is not apparent at the moment.

Six siblings of children with fibrocystic disease were investigated. All were healthy with no clinical evidence of disease. Two of these children were from one family, one having normal and one abnormal sweat. The remaining four were unrelated and of these three had abnormal, and one normal, sweat.

Urea Concentration. Sweat samples from 24 children were also analysed for urea, the results being summarized in Table 2 .

There was a similar wide range of urea concentrations in both normal and fibrocystic groups, with an average concentration in the controls of $181 \mathrm{mg}$./

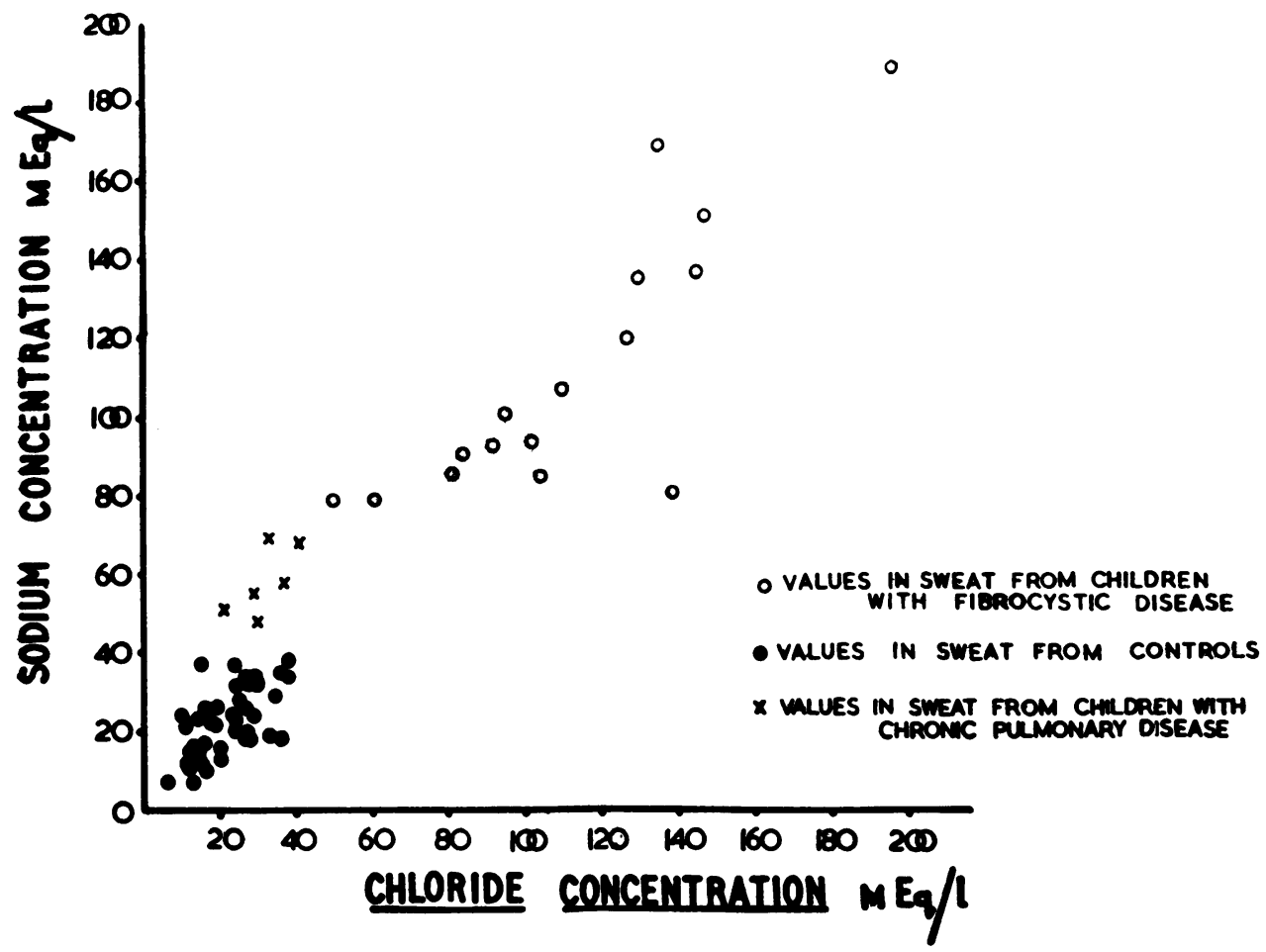

Fig. 2. 
TABLE 2

RESULTS OF UREA ANALYSIS

\begin{tabular}{l|c|c|c}
\hline \multirow{1}{*}{ Group } & \multirow{2}{*}{$\begin{array}{c}\text { Number } \\
\text { of Cases }\end{array}$} & \multicolumn{2}{|c}{ Urea } \\
\hline Controls & Range (mg./l.) & Mean (mg./1.) \\
\hline Fibrocystic disease & 13 & $63-339$ & 181 \\
\hline
\end{tabular}

$100 \mathrm{ml}$. and $191 \mathrm{mg} . / 100 \mathrm{ml}$. in the group of fibrocystic children. Repeat estimations were performed on several children. The results were often far removed from those obtained originally, thus confirming that sweat urea concentrations vary in the individual though tending to exceed blood levels, e.g., in one child with a raised blood urea - $(78 \mathrm{mg} . / 100 \mathrm{ml}$.) the sweat urea was $755 \mathrm{mg}$. $/ 100 \mathrm{ml}$.

Amino-acid Concentration. The amino-acid pattern of the sweat estimated by paper chromatography was similar in both normal and fibrocystic groups and corresponded with the pattern shown by Dent and Walshe (1954).

\section{Discussion}

Since the occurrence in 1948 of heat prostration in 10 children of whom five had fibrocystic disease (Kessler and Andersen, 1951) many papers on abnormal sweat have been published.

The results of di Sant' Agnese, Darling, Perera and Shea (1953), who presented a series of 43 patients and 50 controls, and those of Schwachmann (1956), who investigated 200 patients and 800 controls, show that the concentrations of sweat sodium and chloride in fibrocystic disease are two to four times higher than normal. A similar difference has been obtained in the present series although the range of normality is lower than in previously published papers. This may be due to different methods and conditions of collection. Therefore it would appear that each investigator should establish his own standard according to his method.

The way in which the sweat becomes abnormal in patients with fibrocystic disease and in some of their relatives is unknown. Di Sant' Agnese et al. (1953) demonstrated by metabolic studies that disturbance in neither renal nor adrenal function was responsible, and no change could be seen in the sweat gland when examined microscopically.

Gochberg and Cooke (1956) came to the conclusion that the increased concentration of sodium chloride in sweat from fibrocystic children was due to an increase of sodium chloride in the precursor solution and suggested that there might be an absence of an enzyme, co-enzyme or substrate in secretory cells altering the release of energy producing the abnormal secretion. In this paper he reported sweat urea concentrations in nine children with fibrocystic disease, finding an average of $58 \mathrm{mg} . / 100 \mathrm{ml}$. in controls and $55 \mathrm{mg} . / 100 \mathrm{ml}$. in fibrocystics with little variation.

Examination of the sweat is becoming one of the most useful and reliable diagnostic tests for fibrocystic disease as illustrated by the two cases described.

\section{Case Reports}

Case 1. For three weeks before admission a girl aged 13 months had an exacerbation of the cough present since birth. There was no history of abnornal stools. She was cyanosed and febrile with crepitations heard over both lung fields. Radiographical changes were those of bronchopneumonia.

Analysis of the sweat on two separate occasions gave values typical of those in fibrocystic disease, viz.:

$$
\begin{array}{ll}
\text { Sodium } 92.5 \mathrm{mEq} / 1 . & \text { Chloride } 170.0 \mathrm{mEq} / 1 \text {. } \\
\text { Sodium } 142.0 \mathrm{mEq} / 1 . & \text { Chloride } 86.2 \mathrm{mEq} / 1 \text {. }
\end{array}
$$

A three-day fat balance showed normal fat absorption, there was no excess fat in the faeces on microscopic examination, and the 'lipiodol' test (Silverman and Shirkey, 1955) was not indicative of fibrocystic disease.

Treatment was of no avail and the patient died three months after admission. At necropsy the findings in the pancreas and lungs were typical of fibrocystic disease.

This case resembles one reported by di Sant' Agnese (1955).

Case 2. A boy aged 9 weeks was admitted with suspected fibrocystic disease of the pancreas. He had passed pale, fatty and offensive motions and had failed to thrive. Radiological examination of the lungs revealed bilateral basal consolidation, fat globules were seen in the faeces on microscopical examination, and analysis of the fasting duodenal contents showed no trypsin and a very low activity of lipase.

Despite these findings repeated analyses of the sweat at monthly intervals gave normal results:

$$
\begin{array}{ll}
\text { Sodium } 12.9 \mathrm{mEq} / 1 . & \text { Chloride } 6.8 \mathrm{mEq} / 1 . \\
\text { Sodium } 13.3 \mathrm{mEq} / 1 . & \text { Chloride } 15.9 \mathrm{mEq} / 1 . \\
\text { Sodium } 36.4 \mathrm{mEq} / 1 . & \text { Chloride } 31.2 \mathrm{mEq} / 1 \text {. } \\
\text { Sodium } 18.5 \mathrm{mEq} / 1 . & \text { Chloride } 23.3 \mathrm{mEq} / 1 .
\end{array}
$$

His general condition improved slowly and his motions became normal without treatment. Subsequent analyses of the duodenal fluid revealed first low, and finally normal, activity of lipase and trypsin. It appeared, therefore, that the pancreatic dysfunction had been temporary.

Two other cases, brothers, attended this hospital during recent years. The elder boy had a splenectomy in 1953 when a diagnosis of portal hypertension with oesophageal varices was made. Subsequently he developed a severe pulmonary infection and in 1956 his sweat was found to contain high concentrations of sodium and chloride. His brother, who was thought to have coeliac disease in 1951, was readmitted in 1953 with faecal impaction which necessitated laparotomy. $\mathrm{He}$ has since been found to have fibrocystic disease of 
the pancreas with abnormal sweat. A third child in the family died when 12 days old.

\section{Summary}

A simple method of sweat collection is outlined. Two cases are described in which investigation of the sweat was helpful diagnostically.

The results fall into three groups: sweat from children with fibrocystic disease containing salt in concentrations two to four times that of the concentration in the control group, and children with chronic pulmonary disease having a normal chloride concentration in the sweat but a high sodium value.

There is no difference between the amino-acid and urea conceritrations in controls and children with fibrocystic disease.
We would like to express our gratitude to Professor J. M. Smellie, Mr. H. B. Salt and Dr. O. H. Wolff for their encouragement and helpful criticism; to $\mathrm{Mr}$ A. E. Marston, Chief Pharmacist, for providing the salt-free gauze; to Mr. J. G. Williamson for the photographs; and to the consultant staff of the Children's Hospital, Birmingham, for permitting us to investigate their patients.

\section{REFERENCES}

Dent, C. E. and Walshe, J. M. (1954). Brit. med. Bull., 10, 247. di Sant' Agnese, P. A. (1955). Pediatrics, 15, 683.

-, Darling, R. C., Perera, G. A. and Shea, E. (1953). Ibid. $12,549$.

Gochberg, S. H. and Cooke, R. E. (1956). Ibid., 18, 701.

Kessler, W. R. and Andersen, D. H. (1951). Ibid., 8, 648.

Silverman, F. N. and Shirkey, H. C. (1955). Ibid., 15, 143.

Schwachmann, H. (1956). Personal Communication.

Webb, B. W., Flute, P. T. and Smith, M. J. H. (1957). Arch. D Childh., 32, 82. 